\title{
The Relation between Learning Orientation and Variables of Firm Performance with Strategic Human Resources Management Applications in the Islamic Banks in Turkey
}

\author{
Cemal Zehir ${ }^{1} \&$ Dogan Basar ${ }^{2}$ \\ ${ }^{1}$ Faculty of Economics and Administrative Sciences, Yildiz Technical University, Turkey \\ ${ }^{2}$ Faculty of Business Administration, Gebze Technical University, Turkey \\ Correspondence: Dogan Basar, Faculty of Business Administration, Gebze Technical University, Gebze, Kocaeli, \\ Turkey. Tel: 90-541-269-1661. E-mail: doganbasar@gmail.com
}

Received: January 3, 2015

doi: 10.5539/ibr.v9n3p40
Accepted: January 27, $2016 \quad$ Online Published: February 25, 2016

URL: http://dx.doi.org/10.5539/ibr.v9n3p40

\begin{abstract}
This study is aimed to research the relation between learning orientation and variables of firm performance with Strategic Human Resources Management (SHRM) Applications in the participation banks in Turkey. Labor force planning, education-development, assessing performance, reward system, and withholding employee are used as SHRM Applications. Firm performance is selected as only variable. It has been surveyed on participation banks in Turkey. Results inside the Strategic Human Resources Applications; it was detected that labor force planning is meaningfully impacting on labor force productivity and sales. On the other hand, labor force planning has no correlation with employee turnover rate which is one of the variable of organizational performance. Indeed, employee turnover rate is inversely correlated with sales of the company is detected.

This study is aimed to explore the impact of Strategic Human Resource Management Applications (SHRMA) on learning orientation and firm performance under the conditions of intensive competitive business world where we live today. The variables of the study are Strategic Human Resource Applications, learning orientation, and firm performance. In the analysis, high constative relations of these variables were discussed with a reductant approach. When all the factors are fixed except the variables learn orientation, SHRMA and firm performance, the results of the correlation analyses gives us that the learning orientation, has a significant one to one effect on SHRMA and Firm Performance factors. Moreover, the results of the analyses that SHRMA has a complete mediator variable effect on the relation between Learning Orientation and Firm Performance. This results state a high arity between the variables that we procured via the corresponding structure equation model.
\end{abstract}

Keywords: strategic human resource management applications, firm performance, employee performance, learning orientation, Islamic finance

\section{Introduction}

We compile this research due to the following reasons; to discuss how was effected the relation among Strategic Human Resources, learning orientation, and firm performance during 2015 in Turkey. 2015 is important because the government increase the attached importance on the Islamic Banking by founding Islamic Public Banks where the sector is already intensely competitive.

Nowadays environment is rapidly changing, plus, the globalization and technologic developments is boosting the intensification of the competition. In addition, it is a crystal clear that the companies owe their performance to their cultural competitiveness. Those are aimed at being the best rather aiming to survive. (Miles \& Snow, 1984, 1994; Hult et al., 2003).

The Human Resource Management was accepted as a strategic management issue for reaching to the organizational goals. Human Resources planning is aimed to prepare the action plan on employees. This plan is prepared for the desire of the board on today and in the future. And its way is planning and organizing the necessary attributes, at the right number of employees at the right time. There is a close relationship between Strategic Human Resources Management and Organizational Learning. In order to reach the long term goals of the company, and the company to the competitive targets, it is necessary that Strategic Human Resources 
Management should have to take account the organizational learning into the company management. However, in order to be successful it has a vast importance that company should have to enable a strategically well human resource management and organizational learning.

In the first section of the study we focus on Strategic Human Resources Management approaches. In this section the following subjects are discussed; the development of SHRM over time, its Applications, SHRM approaches, and its subtitles about its relation with firm performance. In the second part, after the learning orientation is discussed, its sub variables are talked over. The firm performance discussed in the third section. At the final part, after creating scales and the scales which are used in the study are gone around, the survey variables, data acquisition, and paradigms are dwelled on. In this section, in addition, hypothesis and limitations are brawly discussed.

\section{Strategic HR Management}

In modern corporations, HR related issues have been inevitable to handle with strategic approaches. The human resources (HR), which is the most important competitive precedence of the organization, has been vehemently demanded to be given strategical importance. The reasons are followings; unstable circumference conditions, occurrence of sophisticated and complicated new type of problems, and seeking of new sorts of management-business understandings (Barutçugil, 2004).

This concept namely Strategic Human Resource Management (SHRM) which has been used and rapidly progressed over time since sometimes beginning of 1980s, due to its supplied benefits and its importance. In those progression period, Human Resources (HR) and Applications (HRA) should have been needed to familiarize with organizational purposes and strategies. This need affected the organizations to consolidate many of their Human Resource Management (HRM) Applications with strategical outputs. This is especially, because of the importance of human resources for strategic achievements of the organizations. From this thought, HRM as a part of the organization; has been catalyzed by macro-organizational approaches on their functions and effects. This process resulted the born and the rise of SHRM (Wright et al., 1998). SHRM has a range of definitions which implies the divergence of the opinion on it. Above all, SHRM is a two dimensional management style with the dimensions; Strategic Management (SM) and Human Resource Management (HRM). With the unification and familiarizing of these two dimensions, the organizations enlarged their vision of management. This contribute to their raison d'être, their goals, and field of activity. Moreover, this unification and familiarizing were mostly restricted companies from the errors of its HR. It has crystal clear results for organizations which are; rapidly running-up, transparently realizing the activities, and easily revealing the goal. About this point, we can cite that "... In the literature of SHRM; the unification is the integration of organizational abilities and the necessities of external demand..."

\section{Strategic Human Resources Approaches}

HRM has been subjected to a variety of survey and been endeavored to be explained by a range of researchers since 1980s (Bayat, 2008). In literature, the HRA has been examined. And many different research accomplished to clarify the results whether is it consistent with different kinds of strategic issues or does it relate to corporate performance (Chan et al., 2005). It is emphasized that HRM with strategic approach had a great importance on cost performance of a company, labor turnover, and adequate efficiency of employees (Richard et al., 2001). To make clear the idea, HRA has a vast impact on the aggregate performance of the corporation.

\subsection{Universalistic Approach}

Universalistic Approach claims that there is always a better HRM application, so that, the organizations should have to accept to perform these Applications (Harel \& Tzafir, 1999). This approach is crowned as "the best application". Nonetheless, it also declare that only the companies which are agree to apply this "best application" will afford an opportunity to be successful. The evidence which are to prove regards universalistic face of SHRM based on company efficiency has comparable outputs, is advocated (Chang et al., 2005). According to this approach, HRA has direct impact on performance (Martin-Alcazar et al., 2005). This relation has been investigated by a number of researcher and they have come up with many supportive outputs.

\subsection{Contingent Approach}

In contrast to the linearity in Universalistic Approach, Generic Contingent Model has been pushed "interaction" to forefront in Contingent Approach. According to this approach, the relation between dependent and independent variables which relation is formally accepted as stable. Plus, it has been investigated as relatively changing with contingent variables. Nevertheless, this approach explained the relation between HRM and performance of a corporation. It says that this relation could not be kept stable for long time. In addition it changes depending upon contingent variables. Ultimately, contingent variables deny to the existence of "best application" which enable to 
perform company, better by playing a mediator role between HRA and performance (Delery et al., 1996).

\subsection{Configurational Approach}

Configurational Approach is more complex about its composition comparing to universalistic and contingent approach (Delery et al., 1996). Configurational models define the function of Human Resources as complex and interactive system in the context of equifinality principle. At the same time it is not denying the contingent approach. The best HR application hypothesis of universalistic approach is refused by the equifinality which is an explanation of this system. It is plausible that approaching to the same end point from original and different initial points make possible to reach maximum performance with original configurations.

Configurational approach embrace the organization as a sophisticated system that involves a range of interior and exterior interconnected sub variables as a part of multivariable's set. The organization is discussed in total. Because this complex structure could not be shuffled with a lonely ingredient (Sheppeck et al., 2005; Yüksel, 2006). Ultimately, the substance is the interior components of the organization which should have to be coherent. At the same time organizational and environmental clauses should be viable (Martin-Alcazar et al., 2005).

\subsection{Contextual Approach}

Contextual approach is suggesting an extended model comparing to former approaches by associating SHRM with circumference orienting as exterior factors. It is discussing all the sectors and regions as a globe. According to the researches sharing this idea, it is not adequate that SHRMA focuses on solely interior operations. Also defining its function on just achieving to the company goals is also not adequate. While other approaches are discussing this idea as at most a conditional variable, this approach scrutinizes the function of Human Resources within the scope of macro-social view by exceeding organizational level. Strategic Human Resources is a conditional variable in line with the strategy of HR. It is more plausible to talk about an interaction. The strategies are not only explained as their contribution to the organizational performance but also they discuss the effects of interior and exterior environments (Martin-Alcazar et al., 2005).

\section{Strategic Human Resources Management Applications}

There are numbers of different policies, Applications, and organizational structures in order to manage the employees of the organization. They are developed to bring the ability to competition of a company into the forefront. There are 6 basic Strategic Human Resources Management Applications (SHRMA) which are mentioned in many researches. Those are; labor force planning, education and development, assessing performance, reward system, employee-firm relations, and communication (Ahmad \& Schroeder, 2003; Becker \& Huselid, 1998; Huang, 2001; Truss, 2001; Tzafrir, 2006). The Strategic Human Resources Management Applications (SHRMA) positively impact on the firm performance. Although nevertheless, there has not been a unanimity on the following question: "what is the best policy and the best application to manage the employees" according to Boselie et al. (2005).

There are many types of SHRMA variables which are suited in organizations. Nonetheless, the importance of unifying the SHRMA differentiate the company from its rivals and bring the success. In order to have an edge over competition, a company should have to attract the best human resources and withhold them in the company. The study below include the SHRMA and firm performance variables.

\subsection{Labor Force Planning}

The researches have indicated that there is a direct correlation between effective labor force planning and firm performance (Cho, 2004). There are dozens of researches that support the idea of "labor force planning decrease the employee turnover rate". On the other hand, the view: "Labor force planning enhances the labor force effectiveness" has been revealed in the researches about the intensive recruitment and employment procedures. These two ideas are used to illustrate the positive impact of labor force planning on profit. Plus, there are researches indicating that labor force planning boost the sales of a company (Ahmad, Schroeder, \& Cho, 2004; Truss, 2001).

\subsection{Education and Development}

The vast positive changes in realizing of company goals and increasing the labor force effectiveness in the low productive companies has been determined by intensifying the education schedules. Education and development activities are indexed as a pioneer part of the high performance work systems (Huselid, 1995; MacDuffie, 1995; Pfeffer, 1994). There are, plus, some studies which slightly proved that education and development activities mitigate the employee turnover rate (Cho, 2004, p. 7; Truss, 2001, p. 1135; Ahmad \& Schroeder, 2003, p. 21). Schuler stated that in a company; education and development activities contain the following steps. Firstly they 
infuse the organization's values, missions and aims into the threshold workers. Secondly these activities determine and put into practice the necessary education programs in order to build up the abilities of the employees. Finally they popularize the education culture among the employees (Schuler, 1998, p. 17).

The study compiled by Bartel (1994) showed that there is a monumental importance of raising the amount of educational programs to achieve the company goals. Moreover, raising the amount of educational programs sustain the effectiveness of the labor force in the low productive companies. The results substantially explain the relation between education and productivity not only at the employee base but also at company base (Bartel, 1994, p. 411). This strong relationship between educated employees and their performance was confirmed by Russell, Terborg and Powers (1985) (Cunha et al., 2003). Moreover, according to many studies in this field, education and development activities are selected as a priority of the work systems for high performance. In contrast, there is only a few empirical studies about outstanding impact of education on the financial and behavioral performance.

\subsection{Assessing Performance}

Assessing the performance is the process to determine whether the employees carry out their duties truly or not. The studies compiled by Wright (2005), Cho (2004), Truss (2001) are implying that assessing performance minimize the rate of employee turnover. Additionally they are leading in this discipline. It was clearly proven that Applications of assessing performance has effects on labor force productivity and the sales (Huselid, 1995; Truss, 2001). According to studies, distinct, tough but reachable objectives and standardized performance assessing processes have a considerable effect on employee productivity (Cho, 2004).

\subsection{Reward System}

The board of directors believes that there is a serious effect of reward system on enhancing the effectiveness of performance and behavioral efficiency. This effect is motivating the performance of employees not only at present but also in the future. On the one hand, monetary rewards increase the performance of employees approximately $39 \%$ in manufacturing companies. In the services sector this rate is about $14 \%$. On the other hand, the level of publicity and prestige activities boost the performance of the employees in the service organizations just over 15\% (Cho, 2004).

It was attested that reward system reduce the employee turnover speed and hike up the level of the effectiveness of labor force and the amount of the sales (Cho, 2004). It was designated by Delaney and Huselid (1996) among 373 public and private sector companies that there is an adequate mutual affinity between reward system and performance. Delaney and Huselid (1996) appointed that promotion system has enormous positive effects on the employees. Additionally, the profound effect of profit share system was explored that it provides the enhancement of productivity and mitigation of elapsed time in absenteeism (Kaufman, 1992).

\subsection{Withholding the Employees}

According to the study prepared by Fryxell and Gordon in 1991, a fair shake and equal treatment to the employees bring favorable outputs in company. This study also indicated that the fair shake and equal treatment in the workplace positively impacted on the loyalty to the organization, profession satisfaction, and performance of the employees (Cho, 2004, p. 28).

\section{Learning Orientation}

As linking the key of the success of the organization and the competition edge, the learning orientation has been discussed in the fields of psychology, management, sociology, market and strategic management.

The aspects of the learning orientation are the following.

\subsection{Commitment to Learning}

Commitment to learning implies how much importance is given to the learning by the company. Moreover, it is related with the Senge's learning principles (1990) which are counseling to be assimilated educational activities as a law by the companies. In other words, companies should have to develop their thinking skills and their putting forward an idea ability (Tobin, 1993). Nevertheless, they should bring forward the understanding of their activities in terms of the causes and effects. Those are stating the behavior of the obedience to learn.

\subsection{Shared Vision (Common Vision)}

As Torben (1993) modified "visible leadership", and Galer and Heijden reorganized "objective synergy", common vision defined as being known and shared the objectives and priorities by the organization. The common vision dominates the behaviors of the members of the organization (Baker et al., 1999; Wang, 2008). Meanwhile shared 
vision appoints the level of developing the understanding of universal organization focus inside the company.

\subsection{Team Orientation}

Team work and learning as a team play a key role in order to become an organization. Because organizations learn by their individual members. Learning as a team, serves as a converter by converting the individual learning into the organization. This is happen by the way of relating the individual learning and organizational learning (Altman \& Iles, 1998, pp. 44-55). Learning as a team, involves the collaboration spirit and the ability of interoperability which is a necessity for the teams to work together. Moreover, learning as a team is established on the followings: Possessing the initiative of the teams, being responsible for their own performance, active communication inside the team, rewarding the successes achieved by team, and having the right to speak in the team. In this way, it is possible to become more effective learning comparing to the personal learning.

\subsection{System Orientation}

System orientation which is used by the managers as a very important instrument in order to make employees to understand clearly, to restructure, and to enhance the intracompany activities and processes. System orientation has the way of converting the market, adversaries, retailers, customers, and other inputs obtained from exterior environment factors to firm outputs (Senge, 1990; Jackson, 1995). In other words, system orientation serves to be perceived of exterior and interior environment factors together, its processes, Applications and actors as a whole by the employees.

\section{Firm Performance}

Performance could be defined as analyzing the rate of realization status of formerly standardized objectives in a certain time period. Here the determined objectives might be aggressive, realistic, or under the capacity of company and its human resources depending on market and the human resources in the market. After the activity ended, the resemblance between the obtained outputs of the activity and the objectives indicate the performance. For instance, the outputs might be equal, less or higher than the objectives. Consequently, performance is the determination of whether to achieve the predetermined objectives by qualitative and quantitative procedures or not. Performance is the way of making the success continuous (Agus et al., 2001). For the companies, on the other hand, it shows whether they reach their predetermined strategical goals. These goals are announced before the performance period. Additionally, they stand for a vital importance at surviving of the company. As a final output of a certain activity, performance is popularized among both academicians around the corporate science and professional managers. It is started become a frequently used indicator. Especially in the literature of Strategic Management field, almost every research both theoretical and empirical are related with the firm performance. However we could not mention about a generally accepted definition of firm performance, even there is no unanimity on it. (Bakoğlu, 2000; Harris et al., 2001).

Firm performance shows the degree of realized objectives in applications and outputs in corporate strategies in a certain time period. In other words, it indicates the level of success (Porter, 1991). The results in the assessing the performance are the critical inputs during the strategical resolution process. These inputs are vital because that they are the indicators of determining the level of success especially in the strategies.

Strategic resolution is the aggregate of the following processes; firstly determining the right means, the right resources and the alternate ways for gaining the competitive edge thereafter sustain it in the competitive environment of the company activate on, and then selecting, applying, and assessing the effectiveness of these processes, finally revising all the processes.

Consequently, firm performance is related with the strategies belonging to the former period inside the competition environment. The essential difference between strategies and performance is about the timing of the applications. For as much as, strategy is subjected the future applications while performance deal with the past periods applications.

\section{Methodology and Findings}

The research plan is prepared as follows. Firstly we determined the research model according to theoretical framework. Then we explored the scales including the survey questions over the literature in order to measure the variables of the research. Thereafter, we composed the best components of the scale among alternatives. After composing, we detected the sample of the research. After that, we acquired data from sample and formed the measurement model by the acquired data. And finally we tested the research hypothesis.

\subsection{Measurement Instrument}

The scales are combined in order to compile the research by acquiring data. All these scales were formerly used 
by internationally valid researches and they are highly confidential. The scale of the Strategic Human Resources Applications are cited from Chen and Huang (2008, p. 10). And the scale of learning orientation is quoted from Hult, Snow and Kandemir (2003). And the scale of the Firm Performance is adapted from the scale of measuring the financial and employee performance.

\subsection{Data Collection}

Both employees and Human Resources Departments in Islamic Banks in Turkey was informed by calling each of them about our research and survey study. Then they were requested if they could attend to our survey questionnaire or not. The survey was answered on web by delivering the online questionnaire to each employees. Employees from all regions of Turkey was incorporated into the Survey.

Islamic banking is the system that supplies fund to the real sectors without using the interest system in the financial sector. It coordinates and operates its banking activities in the view of Islam. Participation Banks, use the fund they collect from savers without using the interest system to the needs of industries and trade organizations as compensation of raw material, bulk product, product, real estate, machine and all sorts of equipment in order to gain profit and they share their profit with the savers of the fund. The participation banks which are not allocating directly cash credits, fulfill the ideal infrastructures of their instruments with having any conflict with Islamic view and develop their services and present them for use of public (Zaim, 2012).

Definitive frequency and statistic values belonging to survey attendees are illustrated table below.

Table 1. Definitive frequency and statistic values belonging to survey attendees

\begin{tabular}{llcc}
\hline & \multicolumn{1}{c}{ Variables } & Number of Employee & Rate (\%) \\
\hline \multirow{4}{*}{ Department } & Marketing and Sales & 100 & 35.5 \\
& Operation & 88 & 31.2 \\
& Accounting/Finance/ Treasury & 19 & 6.7 \\
Gender & Human Resources & 15 & 5.3 \\
& Others & 60 & 21.3 \\
Age & Female & 122 & 26.8 \\
& Male & 160 & 73.2 \\
& Between 23-27 Ages & 119 & 42.2 \\
Between 28-40 Ages & 157 & 55.7 \\
Level of Education & Aged 41 and above & 6 & 2.1 \\
& Primary School & 0 & 0 \\
\hline
\end{tabular}

\subsection{Validity and Reliability of the Measurement Instrument}

The below analysis and methods were used for testing the validity and reliability of the measurement instruments namely scales of the research variables.

In order to reveal to what extend and how much subdimensions were perceived by the attendees of the survey, the exploratory factor analysis (EFA) was progressed by using principle component analyses, estimator, and promax rotation.

In order to test the suitability of the data set for the factor analysis, sample sufficiency test of Kaiser-Meyer-Olkin (KMO) and globularness test of Bartlett were applied. It is revealed after the analysis that the KMO value is 0.818 which is over the desired level 0.50 and the result of the Bartlett test is 0.001 which is significant in terms of importance level (Field, 2009).

The Principle Component Analyses (PCA) was picked as 0.50 by taking into account the lower limit of sample dimension as factor load for each entry (Hair et al., 2010). According to PCA, it is observed that every variables were loaded to the predicted factor component which's factor loads are varied between 0.455 and 0.787 . Furthermore, most of the factor load value was observed over 0.500.

For each factor, the reliability was tested by using Cronbach's Alpha value as base. It is observed that the values on the nail for each factor was climbed over the minimum allowable lower limit value 0.70 . And this result 
reveal that the factors are having internal consistency and reliability. The results of the related factor analysis is illustrated below.

Table 2. Exploratory factor analyses and reliability values

\begin{tabular}{lcccccccc}
\hline Exploratory Factor Analyses & \multicolumn{1}{c}{ item } & item & item & item & item & item & Cronbach's Alpha & Expounded Variance \% \\
\hline Factors & $\mathbf{1}$ & $\mathbf{2}$ & $\mathbf{3}$ & $\mathbf{4}$ & $\mathbf{5}$ & $\mathbf{6}$ & & \\
& 0.893 & 0.755 & 0.684 & & & & 0.83 & 2.96 \\
Education & 0.961 & 0.839 & & & & & 0.84 & 2.67 \\
Reward & 0.549 & 0.839 & & & & & 0.83 & 2.21 \\
Assessing Performance & 0.84 & 0.87 & 0.875 & & & & 0.93 & 6.34 \\
Employment & 0.748 & 0.837 & & & & & 0.81 & 1.93 \\
Withholding & 0.742 & 0.877 & 0.83 & 0.943 & & & 0.91 & 3.22 \\
Team Orientation & 0.582 & 0.848 & 0.734 & 0.944 & 0.879 & & 0.93 & 3.92 \\
System Orientation & 0.800 & 0.722 & 0.856 & & & & 0.91 & 4.23 \\
Commitment to Learning & 0.657 & 0.874 & 0.644 & 0.652 & & & 0.88 & 12.75 \\
Shared Vision & 0.845 & 0.934 & 0.992 & 0.528 & 0.691 & 0.663 & 0.90 & 3.41 \\
Financial Performance & 0.842 & 0.875 & 0.781 & & & & 0.78 & \\
Employee Performance & 0.842 &
\end{tabular}

Note. (i) Principal Component Analyses with Varimax Rotation.

(ii) $\mathrm{KMO}=0.818$ Bartlett Test; $\mathrm{p}<0.001$.

(iii) Total Explained Variance (\%); 84.177.

New variables stating related subdimension were compiled by calculating the arithmetic mean of items loaded for each subdimension, after the scales were revealed by the results of the exploratory factor analyses. Thereafter, the confirmatory factor analysis was realized by loading new variables into the factors as predicted in theory.

The Maximum Feasibility estimator was used in the confirmatory factor analysis and the results of the analysis is illustrated below. All items were loaded statistically and they are significant on their respective variables (with the lowest $\mathrm{t}$ value being 5.707 at $\mathrm{p}<0.01$ ). Items belonging to a factor, which are having average factor load over 0.7 is solicited status, and this condition is indulged. This result implies that scales have convergent validity (Bagozzi et al., 1991).

Table 3. Confirmatory factor analyses

\begin{tabular}{|c|c|c|c|c|c|c|c|}
\hline Factor & Factor Items & Factor Load & Std. Factor Load & $\mathbf{T}$ & $\mathbf{P}$ & Composite Reliability & AVE \\
\hline \multirow{5}{*}{ SHRMA } & Education & 1 & 0.632 & & & \multirow{5}{*}{0.84} & \multirow{5}{*}{0.51} \\
\hline & Reward & 1.085 & 0.592 & 9.539 & $* * *$ & & \\
\hline & Assessing Performance & 1.555 & 0.71 & 9.781 & $* * *$ & & \\
\hline & Employment & 1.725 & 0.851 & 11.038 & $* * *$ & & \\
\hline & Withholding & 1.483 & 0.766 & 10.34 & $* * *$ & & \\
\hline \multirow{4}{*}{ Learning Orientation } & Team & 1 & 0.974 & & & \multirow{4}{*}{0.88} & \multirow{4}{*}{0.66} \\
\hline & System & 0.838 & 0.839 & 13.285 & $* * *$ & & \\
\hline & Learning & 0.691 & 0.686 & 9.832 & $* * *$ & & \\
\hline & Shared Vision & 0.689 & 0.712 & 11.447 & $* * *$ & & \\
\hline \multirow{2}{*}{ Firm Performance } & Financial Performance & 1 & 0.779 & & & \multirow{2}{*}{0.72} & \multirow{2}{*}{0.53} \\
\hline & Employee Performance & 1.006 & 0.671 & 5.707 & $* * *$ & & \\
\hline
\end{tabular}

Note. $\mathrm{X} 2 / \mathrm{df}=3.881, \mathrm{GFI}=0.915, \mathrm{IFI}=0.922 \mathrm{CFI}=0.921, \mathrm{SRMR}=0.056(* * * \mathrm{p}<0.001)$.

The values named goodness of fit index is used to test the statistical relevance of the theoretic model in structural equation model. The goodness of fit index values used in the study are X2/df, SRMR, GFI, IFI, CFI. The goodness of fit index used in the confirmatory factor analyses are X2/df $=3,881, \mathrm{GFI}=0,915, \mathrm{IFI}=0,922$ $\mathrm{CFI}=0,921, \mathrm{SRMR}=0,056$. Plus, the existence of a generally acceptable fitness inside the facto analyses is observed (Schumacker \& Lomax, 2004). 
The values of AVE (Average Variance Extracted) (Fornell \& Larcker, 1981) and SCR (Scale Composite Reliability) (Bagozzi \& Yi, 1988) are used to test the reliability of the factors. It could be explained that factors are valid and reliable when the AVE value is 0.5 and CR value is 0.7 (Bagozzi \& Yi, 1988). The AVE and SCR values belonging to the factors of the study illustrated above. This results show that the reliability and validity of the factors are at the solicited level.

The results of the correlation analyses stated that there is a significant and positive relationship among the factors. Moreover, it is observed that the discriminant validity is satisfied. This satisfaction is depend on the fact that the square root of AVE values for each factor are greater than the correlation values which are generated between the corresponding factor and other factors (Hair et al., 2010).

Table 4. Correlation analyses

\begin{tabular}{lccc}
\hline Factors & Learning Orientation & SHRMA & Performance \\
\hline Learning Orientation & 0.81 & & \\
SHRMA & $0.67^{* *}$ & 0.72 & \\
Performance & $0.26^{* *}$ & $0.50^{* *}$ & $0.73^{* *}$ \\
\hline
\end{tabular}

Note. ** Correlations are significant at the level of 0.01. Diagonal values are representing the square roots of AVE values.

\subsection{Test of the Research Model}

In order to test the research hypothesis, the regression analyses was realized by using the structural equation model technique.

The research hypothesis are stated below;

$\mathrm{H}_{1}$; Learning Orientation significant and positively effects on SHRMA.

$\mathrm{H}_{2}$; Learning Orientation significant and positively effects on Firm Performance.

$\mathrm{H}_{3}$; SHRMA significant and positively effects on Firm Performance.

The results of the regression analyses which was realized by using the structural equation model technique in order to test the research hypothesis, is stated below.

Table 5. Regression analyses

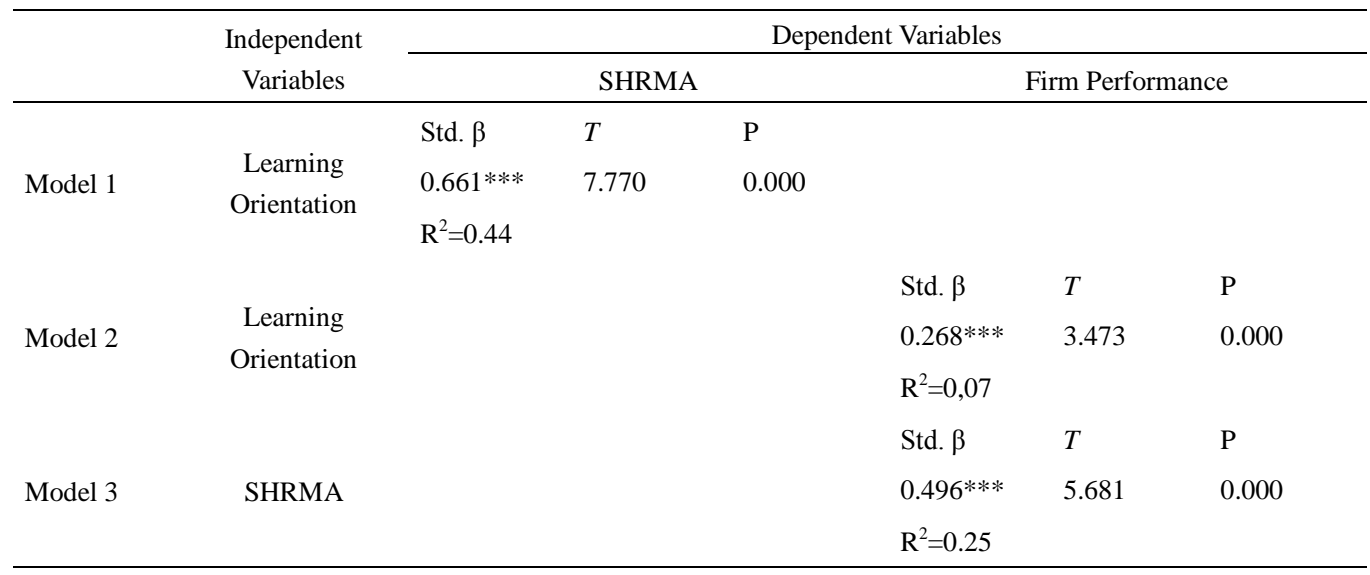

According to Model 1, variable of Learning Orientation significant and positively effects on variable of SHRMA $(\beta=0.661 ; \mathrm{p}<0.01)$.

According to Model 2, variable of Learning Orientation significant and positively effects on variable of Firm Performance $(\beta=0.268 ; \mathrm{p}<0.01)$.

According to Model 3, variable of SHRMA significant and positively effects on variable of Firm Performance $(\beta=0.496 ; \mathrm{p}<0.01)$.

The multiple correlation coefficient $\left(\mathrm{R}^{2}\right)$ indicates the statement percentage of the independent variable of 
dependent variables. It is conferred that the Learning Orientation variable, accordingly, clarifies $44 \%$ of the SHRMA variable and $7 \%$ of the Firm Performance variable. Plus, SHRMA variable clarifies $25 \%$ of Firm Performance variable.

The study hypothesis compiled for the possible mediator variable of SHRMA in the relation between Learning Orientation and Firm Performance is stated below.

$\mathrm{H}_{4}$; Learning Orientation significant and positively effects on Firm Performance via SHRMA

The results of the regression analyses which was realized by using the structural equation model technique in order to test the research hypothesis, is stated below.

Table 6. The effect of mediator variables on SHRMA

\begin{tabular}{|c|c|c|c|c|c|c|c|c|c|c|}
\hline \multirow{5}{*}{ Model 4} & & \multicolumn{3}{|c|}{ SHRMA } & \multicolumn{3}{|c|}{ Firm Performance } & \multicolumn{3}{|c|}{ Indirect Effect } \\
\hline & & Std. $\beta$ & $T$ & $\mathrm{P}$ & Std. $\beta$ & $t$ & $\mathrm{P}$ & Estimate & \multicolumn{2}{|c|}{ Confidence Intervals } \\
\hline & SHRMA & & & & $0.592 * * *$ & 5.218 & 0 & & \multicolumn{2}{|l|}{$\mathrm{BC}$} \\
\hline & Learning Orientation & $0.666 * * *$ & 7.98 & 0 & -0.138 & -1.59 & 0.112 & & & \\
\hline & & \multicolumn{3}{|c|}{$\mathrm{R}^{2}=0.44$} & \multicolumn{3}{|c|}{$\mathrm{R}^{2}=0.26$} & & Lower & Upper \\
\hline \multicolumn{2}{|c|}{ Mediating Effect } & & LO & & \multicolumn{3}{|c|}{ SHRMA FP } & $0.207 * * *$ & 0.12 & 0.33 \\
\hline \multicolumn{8}{|c|}{$\mathrm{X} 2 / \mathrm{df}=3.881, \mathrm{GFI}=0.915, \mathrm{IFI}=0.922 \mathrm{CFI}=0.921, \mathrm{SRMR}=0.056(* * * \mathrm{p}<0.001)$} & \multicolumn{3}{|c|}{$\begin{array}{l}5000 \text { Bootstrap Samples } \\
\% 95 \text { Confidence Interval }\end{array}$} \\
\hline
\end{tabular}

According to above regression analyses, before the mediator variable step in, the effects of Learning Orientation on variable of Firm Performance are significant and positive $(\beta=0.268 ; p<0.01)$. However, when the mediator variable step in (Model 4), it is observed that the effects of Learning Orientation on Firm Performance disappear.

For measuring the possible mediator effects, financial performance variable was explored by using the "Bootstrap" method (Preacher \& Hayes, 2004). This exploration was made for determining indirect effects of cost leadership strategy variable over 5000 samples. Consequently, it is observed that the mediator effect is valid due to the existence of indirect effect $(\beta=0,207 ; p<0,001)$ at the level of $95 \%$ confident interval it is significant.

Ultimately, $\mathrm{H}_{4}$ was accepted. Hence, it is embodied that SHRMA has a complete mediator variable effect on the relation of Learning Orientation and Firm Performance. The graph of the results of the corresponding Structural Equation Modelling is illustrated below.

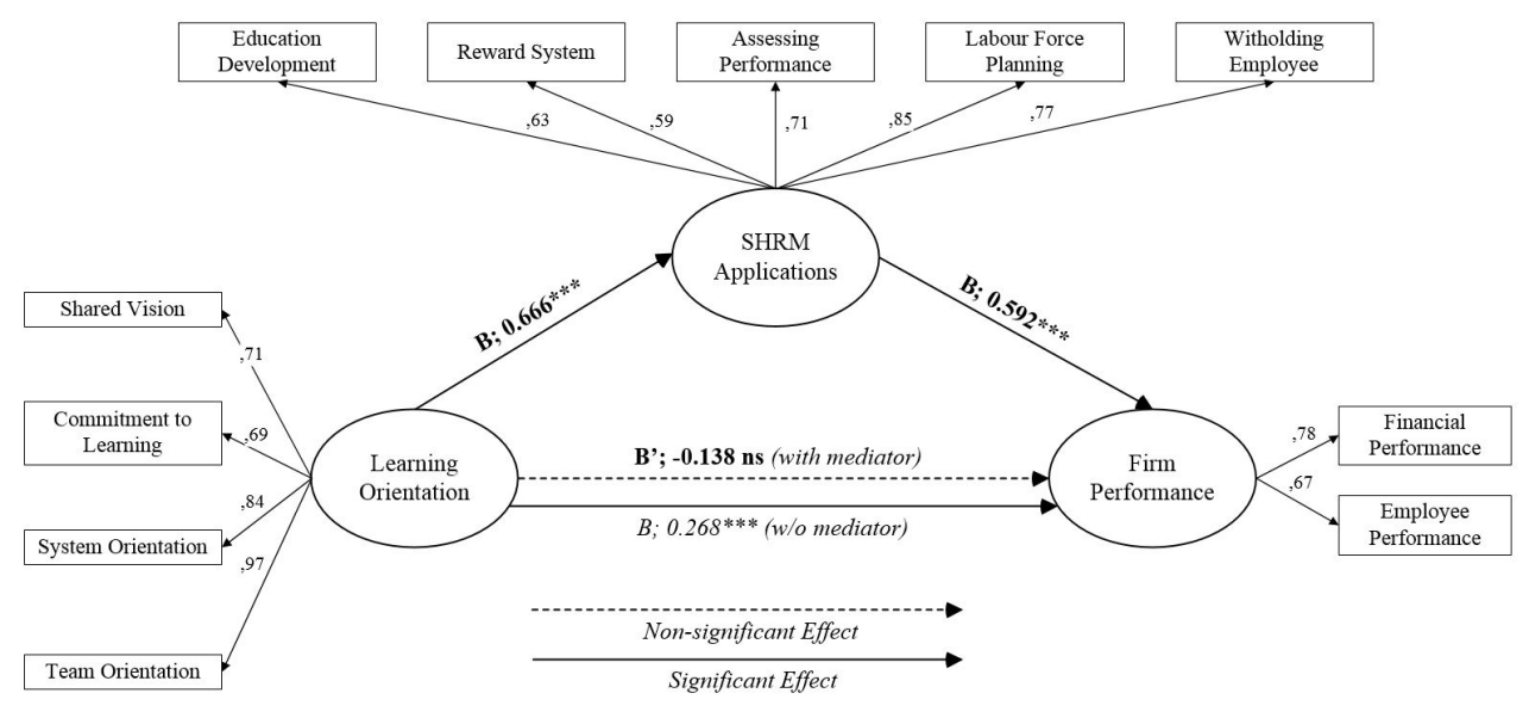

Figure 1. Proposed model 


\section{Discussion and Conclusion}

The Learning Orientation which is an ongoing issue over the strategical orientations of business economics literature in terms of cognitive and empirical studies. Also it is subjected to practical field researches or it is frequently a matter in hand. At the same time it is a dimension of the strategical orientations. Ultimately, it is discussed within a logical framework as a cognitive issue on our study. Similarly, Strategic Human Resource Management Applications and Firm Performance criteria have been frequently used in studies. Moreover, they are detected and discussed based upon studies which associated the Strategic Human Resource Applications and Firm Performance.

It is the basic result of the correlation analyses that Learning Orientation has individually one to one effect on the success at a competitive environment of the participation banks in Turkey. When all the factors are fixed except the variables learn orientation, SHRMA and firm performance, the results of the correlation analyses gives us that the learning orientation, has a significant one to one effect on SHRMA and Firm Performance factors. Furthermore, the $\mathrm{H} 4$ hypothesis is appeared by the results of the analyses that SHRMA has a complete mediator variable effect at the relation of Learning Orientation and Firm Performance. This is an original result that we procured via the corresponding structure equation model.

We can clearly say the followings depending on the results of the study; an active SHRMA could be used as an efficient instrument for creating the desired learning. Hence, it positively effects the firm performance both employee and financial bases. For the board of directors, taking in consideration and realizing the ideas of the employees brings both profit and loss probabilities for the future of the company. If this is not disincentive for the board of directors, it shouldn't be for the employees too. Hence, the successful Applications should be certainly incentivized while the gracious but unsuccessful ideas should not be punished. Punishing the firm members for the learning orientation Applications remains the strategic objectives going astray therefore it negatively affect the performance. If the board of directors accept the Human Resources as a strategic partner when determining the short, middle and long term objectives, it moves the company to the success. Similarly, it is obvious that shared common vision and learning make the employees to contribute to the system by team-vise.

We compile this study on Islamic Banking due to its growing importance in Turkey nowadays. This study, in the future, either able to apply on whole banking sector or taking with the other dimensions of strategic orientations it gives different results. Moreover, with involving the Strategic Human Resource Management inside the study it is obvious that the moderator effect come up with more different results. When taking into account the growing effects of modern managing techniques on the business environment and the contributions of CEOs to the organizations, it is clear that many considerable results could be gained by taking in hand the subject of the study with leadership approaches.

\section{References}

Agus, A. S., \& Ridzuan, M. (2001). The Structural Relations Between Total Quality Management, Competitive Advantage and Bottom Line Financial Performance: An Emprical Study of Malasian Manufacturing Companies. Total Quality Management, 12(7-8), 1018-1024.

Ahmad, S., \& Schroeder, R. G. (2003). The impact of human resource management practices on operational performance: Recognizing country and industry differences. Journal of Operations Management. http://dx.doi.org/10.1016/S0272-6963(02)00056-6

Ahmad, A. (1987). Development and Problems of Islamic Banks. Jeddah: Islamic Research and Training Institute, Islamic Development Bank, 1-152.

Altman, Y., \& Iles, S. (1998). Learning, Leadership, Teams: Corporate Learning and Organizational Change. Journal of Management Development, 17(1), 44-55. http://dx.doi.org/10.1108/02621719810368682

Bagozzi, R. S., \& Youjae, Y. (1988). On the evaluation of structural equation models. Journal of the academy of marketing science, 16(1), 74-94. http://dx.doi.org/10.1007/BF02723327

Bagozzi, R. S., Youjae, Y., \& Lynn, W. P. (1991). Assessing construct validity in organizational research. Administrative Science Quarterly, 36(3), 421-458. http://dx.doi.org/10.2307/2393203

Baker, W. E., \& Sinkula, J. M. (1999). The synergistic effects of market orientation and learning orientation on organizational performance. Journal of Academy of Marketing Science, 27(4), 411-427. http://dx.doi.org/10.1177/0092070399274002

Bakoğlu, R. (2000). Organizational Performance. The Journal of Oneri, 15, 39-45.

Bartel, A. (1994). Productivity Gains from the Implementation of EmployeeTraining Programs. Industrial 
Relations, 33, 411-425. http://dx.doi.org/10.1111/j.1468-232X.1994.tb00349.x

Barutçugil, \& İsmet. (2004). Strategic Human Resource Management. İstanbul: Kariyer Yayınc1lık.

Bayat, B. (2008). Strategic of Human Resource, Gazi University. The Journal of Business Administration, 10(3), 67-91.

Becker, B. E., \& Ve Huselid, M. A. (1998). High Performance Work Systems and Firm Performance: A Synthesis of Research and Managerial Implications. Research in Personnel and Human Resources, Stamford CT: JAI Press.

Boselie, P., Dietz, G., \& Boon, C. (2005). Commonalities and Contradictions in HRM and Performance Research. Human Resource Management Journal, 15(3), 67-94. http://dx.doi.org/10.1111/j.1748-8583.2005.tb00154.x

Chang, W. J. A., \& Huang, T. C. (2005). Relationship between Strategic Human Resource Management and Firm Performance. International Journal of Manpower, 26(5), 434-474. http://dx.doi.org/10.1108/01437720510615125

Cho, Y. S. (2004). Examining the Impact of Human Resource Management: A Performance Based Analytic Model. Las Vegas, University Nevada, Unpublished PhD, Dissertation, USA.

Cunha, R. C., Cunha, M. P., Morgado, A., \& Brewster, C. (2003). Market Forces, Strategic Management, HRM Practices and Organizational Performance, A Model Based in a European Sample. Journal of Management Research, 1-28.

Day, G. S. (1994a). Continous Learning about Markets. California Management Review, 36, 9-31. http://dx.doi.org/10.2307/41165764

Delery, J. E., \& Doty, D. H. (1996). Modes of Theorizing in Strategic Human Resource Management: Test of Universalistic Contingency, and Configurational Performance Predictions. The Academy of Management Journal, 39(4), 802-835. http://dx.doi.org/10.2307/256713

Field, A. (2009). Discovering Statistics Using SPSS (3rd ed.). London: Sage.

Hair, J. F. et al. (2010). Multivariate Data Analysis: A Global Perspective (7th ed). Upper Saddle River: Prentice Hall.

Harel, G. H., \& Tzafrir, S. S. (1999). The Effect of Human Resource Management Practices on the Perceptions of Organizational and Market Performance on the Firm. Human Resource Management, 38(3), $185-200$. http://dx.doi.org/10.1002/(SICI)1099-050X(199923)38:3<185::AID-HRM2>3.0.CO;2-Y

Harris, L., \& Ogbonna, E. (2001b). Strategic Human Resource Management, Market Orientation, and Organizational Performance. Journal of Business Research, 51(2), 157-166. http://dx.doi.org/10.1016/S0148-2963(99)00057-0

Huang, T. C. (2001). The effects of linkage between business and human resource management strategies. Personnel Review, 30(2), 132-151. http://dx.doi.org/10.1108/00483480110380316

Hult, G. T., Snow, C., \& Kandemir, D. (2003). The Role of Entrepreneurship in Building Cultural Competitiveness in Different Organizational Types. Journal of Management, 29(3), 401-426. http://dx.doi.org/10.1016/S0149-2063(03)00017-5

Hult, G. T. M. (1998). Managing the International Strategic Sourcing Function as a Market-Driven Organizational Learning System. Decision Sciences, 29(1), 193-216. http://dx.doi.org/10.1111/j.1540-5915.1998.tb01349.x

Hult, G. T. M., Ferrel, O. C., \& Hurley, R. (2002). Global Organizational Learning Effects on Cycle Time Performance. Journal of Business Research, 55, 377-387. http://dx.doi.org/10.1016/S0148-2963(00)00161-2

Hult, G. T. M., Nichols, J. E. L., Giunipero, L. C., \& Hurley, R. F. (2000). Global Organizational Learning in the Supply Chain: A Low versus High Learning Study. Journal of International Marketing, 8(3), 61-83. http://dx.doi.org/10.1509/jimk.8.3.61.19628

Huselid, M. A. (1995). The Impact of Human Resource Management Practices on Turnover, Productivity, and Corporate Financial Performance. Academy of Management Journal, 38(3), 635-672. http://dx.doi.org/10.2307/256741

Hwang, A. S. (2000). Toward Fostering Systems Learning in Organizational Contexts. Systemic Practice and Action Research, 13(3), 239-343.

Jackson, M. C. (1995). Beyond the Fads: Systems Thinking for Managers. Systems Research, 12(1), $25-42$. 
http://dx.doi.org/10.1002/sres.3850120106

Kaufman, T. R. (1992). The Effects of Improshare on Productivity. Industrial and Labor Relations Review, 45(2), 311-322. http://dx.doi.org/10.1177/001979399204500208

Lynch, D. F., Keller, S. B., \& Ozment, J. (2000). The effects of logistics capabilities and strategy on firm performance. Journal of Business Logistics, 21(2), 47-67.

Macduffie, J. P. (1995). Human Resource Bundles and Manufacturing Performance: Organizational Logic and Flexible Production Systems in the World Auto Industry. Industrial and Labor Relations Review, 48(2), 197-221. http://dx.doi.org/10.1177/001979399504800201

Martin-Alcazar, F., Romero-Fernandez, P. M., \& Sanchez-Gardey, G. (2005). Strategic Human Resource Management: Integrating the Universalistic, Contingent, Configurational, and Contextual Perspectives. International Journal of Human Resource Management, 16(5), 633-659. http://dx.doi.org/10.1080/09585190500082519

Miles, R. E., \& Snow, C. C. (1984). Fit, Failure, and Hall of Fame. California Management Review, 26, 10-28. http://dx.doi.org/10.2307/41165078

Miles, R. E., \& Snow, C. C. (1994). Fit, Failure, and Hall of Fame: How Companies Succeed or Fail. New York: The Free Press.

Pfeffer, J. (1994). Competitive Advantage Through People. Boston, MA: Harvard Business School Press.

Porter, M. E. (1991). Towards a Dynamic Theory of Strategy. Strategic Management Journal, 12, 95-117. http://dx.doi.org/10.1002/smj.4250121008

Preacher, K. J., \& Hayes, A. F. (2004). SPSS and SAS procedures for estimating indirect effects in simple mediation models. Behavior Research Methods, Instruments, \& Computers, 36(4), 717-731. http://dx.doi.org/10.3758/BF03206553

Richard, \& Johnson. (2001). Strategic Human Resource Management Effectiveness and Firm Performance. International Journal of Human Resource Management, 12(2), 299-310. http://dx.doi.org/10.1080/09585190121674

Sackmann, S. A. (1991). Cultural Knowledge in Organizations. Newbury Park, CA:Sage.

Schein, E. H. (1992). Organizational Culture and Leadership (2nd ed.). San Francisco: Jossey-Bass.

Schuler, R. S. (1998). Managing Human Resources. South-Western College Publishing.

Schumacker, R. E., \& Lomax, R. G. (2004). A Beginner's Guide to Structural Equation Modeling (2nd ed.). Lawrence Erlbaum Associates, Publishers, Mahwah, New Jersey.

Senge, S. M. (1990). The fifth discipline: The art and practice of learning organization. New York: Doubleday.

Sheppeck, M. A., \& Ve Militello, J. (2005). Strategic HR Configurations and Organizational Performance. Human Resource Management, 39(1), 5-16.

Tobin, D. R. (1993). Reeducating the Corporation: Foundations for the Learning Organization. Essex Junction, VT: Oliver Wright.

Truss, C. (2001). Complexities and Controversies in Linking HRM with Organizational Outcomes. Journal of Management Studies, 38(8), 1122-1149. http://dx.doi.org/10.1111/1467-6486.00275

Tzafrir, S. S. (2006). A Universalistic Perspective for Explaining the Relationship between HRM Practices and Firm Performance at Different Points in Time. Journal of Managerial Psychology, 21(2), 109-130. http://dx.doi.org/10.1108/02683940610650730

Wang, C. L. (2008). Entrepreneurial Orientation, Learning Orientation, and Firm Performance. Entrepreneurship Theory and Practice, 635-657. http://dx.doi.org/10.1111/j.1540-6520.2008.00246.x

Wright, P. M., Gardner, T. M., \& Moynihan, L. M. (2003). The Impact of HR Practices on the Performance of Business Units. Human Resource Management Journal, 13(3), 21-36. http://dx.doi.org/10.1111/j.1748-8583.2003.tb00096.x

Wright, P. M., Gardner, T. M., Moynihan, L. M., \& Allen, M. R. (2005). The Relationship Between HR Practices and Firm Performance: Examining Causal Order. Personnel Psychology, 58, 409-446. http://dx.doi.org/10.1111/j.1744-6570.2005.00487.x

Yuksel, O. (2004). Human Resource Management. Gazi Kitabevi, Ankara. 
Zahra, S. A., Neubaum, D. O., \& El-Hagrassy, G. M. (2002). Competitive analysis and new venture performance: Understanding the impact of strategic uncertainty and venture origin. Entrepreneurship Theory and Practice, 1-28. http://dx.doi.org/10.1111/1540-8520.t01-2-00001

\section{Copyrights}

Copyright for this article is retained by the author(s), with first publication rights granted to the journal.

This is an open-access article distributed under the terms and conditions of the Creative Commons Attribution license (http://creativecommons.org/licenses/by/3.0/). 